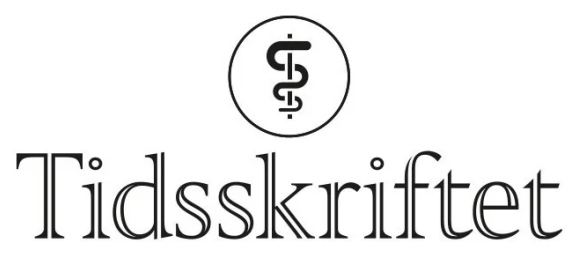

DEN NORSKE LEGEFORENING

\title{
Lite eller stort - smått, men godt?
}

KOMMENTAR

\section{TORE GUDE}

toregude7@gmail.com

Tore Gude er spesialist i psykiatri og professor emeritus ved Universitetet i Oslo.

Forfatteren har ikke oppgitt noen interessekonflikter.

Tidsskrift nr. 1/2022 har som hovedoppslag: «Hvor skal legene utdannes?» I flere artikler, inkludert leder (1) , omtales ordningen med desentralisert utdanning av medisinstudenter med den hensikt å styrke rekrutteringen til stillinger i distriktene, i første rekke til primærhelsetjenesten. I lederartikkelen henvises det til erfaringer fra andre land som Nasjonalt senter for distriktsmedisin har samarbeidet med, bl.a. Sverige og Island. Samarbeidet har dreid seg om utviklingen av en strategisk modell for å rekruttere og beholde helsepersonell i distriktene. Modellen baserer seg på langsiktig tenkning $\mathrm{i}$ planutformingene.

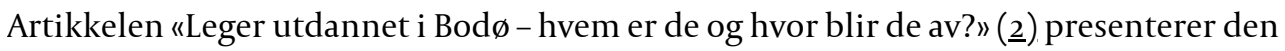
såkalte Bodø-pakken som ble etablert i 2009 da Universitetet i Troms $\emptyset$ av kapasitetshensyn flyttet de to siste årene av medisinstudiet til Bodø og Bodø-området. Ved å følge de totalt 146 legene som deltok i denne ordningen fant en at sannsynligheten for senere arbeidssted i distriktet økte dersom legens oppvekststed hadde vært i samme område. Videre at Bodøpakken hadde rekruttert godt til allmennmedisin i Bodø-regionen samt i øvrige del av Nordland.

I EKKO-prosjektet (Evaluering av klinisk kommunikasjon - i medisinstudiet), gjennomført på begynnelsen av 20oo-tallet i et samarbeid mellom representanter for de fire medisinske fakulteter, fremkom interessante funn med relevans for debatten om hvor utdanningen bør foregå. Det nevnte prosjektet omhandlet bl.a. utviklingen av kliniske kommunikasjonsferdigheter fra studie-slutt til turnus-slutt. Resultatene viste at unge leger som hadde hatt sin turnustjeneste på mindre lokale sykehus hadde en signifikant bedring av sine kommunikasjonsferdigheter sammenlignet med leger som hadde hatt tilsvarende tjeneste på større sentral/regionsykehus (3). En mulig forklaring var at på mindre lokalsykehus var det lettere å følge egne pasienter og at læringsmiljøet var bedre egnet for ferske leger enn på de store sykehusene. Selv om denne fremgangen $\mathrm{i}$ kommunikasjonsferdigheter gjaldt for kvinnelige leger, ikke mannlige, og studien ble gjennomført i turnustiden, ikke under studiet - kan det likevel støtte oppunder de fordelene som desentralisert undervisning har vist seg å ha.

Slagordet «lite, men godt», eller enda mer presist: «smått, men godt» er høyst relevant i medisinutdanningen. 


\section{REFERENCES}

1. Thoresen M. Leger til distriktet - bruk mulighetene. Tidsskr Nor Legeforen 2022; 142. doi: 10.4045/tidsskr.21.0839. [PubMed][CrossRef]

2. Westlie ÅL, Gaski M, Abelsen B et al. Leger utdannet i Bodø-hvem er de og hvor blir de av? Tidsskr Nor Legeforen 2022; 142. doi: 10.4045/tidsskr.21.0254. [PubMed][CrossRef]

3. Gude T, Vaglum P, Anvik T et al. Do physicians improve their communication skills between finishing medical school and completing internship? A nationwide prospective observational cohort study. Patient Educ Couns 2009; 76: 207-12. [PubMed][CrossRef]

Publisert: 28. februar 2022. Tidsskr Nor Legeforen. DOI: 10.4045/tidsskr.22.0103

(C) Tidsskrift for Den norske legeforening 2023. Lastet ned fra tidsskriftet.no 26. april 2023. 